\title{
Responsive Jurisprudence: An Empirical Examination of Chinese People's Mediation in Practice
}

\author{
Shahla $\mathrm{Ali}^{\ddagger}$ \\ HKU Working Paper \\ January 11, 2013
}

Community mediation in China has a long history and finds its roots in both cultural and functional aims. Recently however, owing to changes in societal values occurring alongside China's economic open door policy, traditional values are losing their prominent role in the mediation process. Meanwhile, reforms are being carried out to provide greater structure to community mediation in China. The combination of these changes has resulted in struggles to redefine the place and role of mediation in China. Whilst the flexibility and responsiveness of mediation allows a contextualized and 'learning mode of legal intervention', it is at risk of being a 'precarious ideal' that lacks precision. Nevertheless, empirical research shows that a new version of mediation which is embedded in the 'rule of law' is emerging and that responses from mediators in relation to this new mode of mediation are positive, reporting enhancement in both objectivity and legitimacy.

This paper seeks to explore the unique challenges and opportunities of achieving responsive mediation in action in China. Drawing on a set of interviews and a case study conducted in three cities in China, the paper aims to contribute to the legal pluralism discourse by examining how mediation in China, traditionally an "unofficial" form of legal practice is now becoming "official" through state sanction and how mediators interact with traditional Confucian normative orders in the context of changing social priorities and values. This paper is divided into 3 parts: Part I will discuss briefly the jurisprudence of responsive law; Part II will examine contemporary mediation policy in China which echoes in many respects the goals and challenges of responsive law; and Part III will provide an empirical exploration of the challenges of applying responsive law ideals in practice.

\footnotetext{
‡ Assistant Professor of Law and Deputy Director, LLM in Arbitration and Dispute Resolution, Faculty of Law, University of Hong Kong. B.A., Stanford University; M.A., Landegg International University, Switzerland; J.D., Boalt Hall School of Law, University of California at Berkeley; Ph.D, Jurisprudence and Social Policy Program, University of California at Berkeley. The author thanks the University of Hong Kong Research Committee for its kind support of this project. The author also thanks the many mediators and legal practitioners in China who participated in the research.
} 


\section{Introduction: Responsive Law Jurisprudence and Legal Pluralism}

Responsive law as an ideal type bears many parallels with the aspirations of community mediation and finds many areas of convergence with the legal pluralism literature. The idea of responsiveness can be traced to insights developed by Philippe Nonet and Philip Selznick in the late 1970's, who sought to address the perceived tradeoff between substantive and procedural justice and to fill the gap between the two (Nonet, Selznick and Kagan 2001: xi). Mere order within the context of 'repressive law' or legitimacy in the context of 'autonomous law' (Horwitz 1969: 9$31)^{1}$ were seen as deficient when it came to the more important task of responding to societal needs and objectives (Nonet, Selznick and Kagan 2001: 14-15). According to Nonet and Selznick (2001), in the realm of responsive law, law is seen as 'a facilitator of response to social needs and aspirations'. To achieve this end, much depends on the capacity of legal practitioners and policy makers:

to develop new institutional methods for gauging social needs and to devise sensible, politically feasible, and socially acceptable legal remedies (Nonet, Selznick and Kagan 2001).

Drawing on strands within the legal process school and the pragmatic model which emphasizes process as a way of overcoming the indeterminacy of rules that legal realists exposed (see Alberstein 2009 citing Horwitz 1969: 247-268), legal decisionmaking came to be seen as 'reasoned elaboration' (White 1973), which inspired the basic ideas of the pragmatic approach to mediation and its principles of problem solving (Alberstein 2002: 251-320). The pragmatic model similarly emphasizes process (Fisher and Ury 1983: 8-10) and draws on the constructive concepts of expanding the pie (see Alberstein 2009 citing Hart et al. 1994). ${ }^{2}$

At its best, responsive law 'aims at enablement and facilitation', and a 'blending of powers and a blurring of institutional boundaries' (Nonet, Selznick and Kagan 2001: 111). 'Responsiveness', while carrying multiple meanings, is understood here as an alternative decision making mode that aims for a more 'contextualized and ultimately learning mode of legal intervention' (Zumbansen 2008). Responsive law 'requires that legal institutions and legal ideas be open to social knowledge and attentive to all legitimate interests, whilst at the same time the legal system retains its own basic commitments and its capacity to function' (Selznik 1992: 463-475). It seeks to aspire and fulfill the requirements of 'good law', in that it insists that: 'evaluation await a close assessment of actual problems, resources and opportunities' (Nonet, Selznick and Kagan 2001: 25).

\footnotetext{
${ }^{1}$ Horwitz (1969) discussed legal formalism's view of law as a body of formal legal rules and that mastering its internal language is the main business of the lawyer and the legal intellect. In particular, Christopher Columbus Langdell, former Dean of Harvard Law School, advocated a scientific, detached approach to law. He treated law as an academic and scientific field with a set of rules for judges to apply mechanically to the issues at hand.

2 "These materials proceed upon the conviction that this is a fallacy_-"the fallacy of the static pie." the fact - the entirely objective fact - seems to be that the pie - that is, the total of actually and potentially available satisfactions of human wants-is not static but dynamic. How to make the pie larger, not how to divide the existing pie, is the crux of the long-range and primarily significant problem.'
} 
It is in this context of close assessment of actual problems that the aims and objectives of legal pluralism are most directly applied. Addressing the conceptual challenges brought about by globalization, legal pluralism scholars beginning in the $20^{\text {th }}$ century embarked on an effort to describe the diverse contexts "in which two or more legal systems coexist in the same social field" (Pospisil, 1971; Griffiths, 1986a; Moore, 1986a). Research focused largely on the interaction between European forms of law and indigenous legal systems of Africa, Asia, and the Pacific (Merry, 1988). Legal pluralism advanced the idea of the "semi-autonomous social field" which captures the porosity of the social and normative contexts of legal orders (Moore, 1978, 1981). These are fields that are not confined to national boundaries, but rather recognize that local, national, transnational, regional, and global orders can all overlap and apply to the same condition or situation (Twining, 2000).

In recent years, empirical and participatory research has made a significant contribution to legal pluralism studies (Wiber 2010) by helping to address the conceptual as well as theoretical challenges associated with drawing distinctions between legal and non-legal phenomena and between legal orders, systems, traditions, and cultures (Twining, 2000). More recently, with legal pluralism scholarship examining how empirical verification can illustrate the extent to which legal conceptions are shared and meaningful to a particular set of people, (Wiber 1995) legal pluralism has contributed to a greater understanding of both the normative and descriptive complexities of multiple legal systems interacting in a complex and dynamic environment. Its descriptive contribution calls attention to the "coexistence and interaction of different forms and sources of law" and draws focus on the notion that legislatures and courts are only two among the diverse forms of legal order that regulate people's lives (Selznick, 1992). Its normative import lies in the importance it places on institutions that are close to the people. These institutions are said to have a prima facie claim to respect, forbearance, and support because "they are valued as extensions of personhood, as settings within which social participation is most direct and most effective" (Selznick, 1992).

At its worst, Nonet and Selznick (2001) acknowledge that responsiveness is a 'precarious ideal' and the nature of responsive law is often a subjective question. Nonet and Selznick (2001) acknowledge that responsive law is a 'high risk' mode of governance because the more flexible law is, the higher the risk of law being too malleable and thus eroding the authority of legal institutions (Nonet, Selznick and Kagan 2001: xii). Although openness may bring flexibility, it loses precision. This may lead to elusiveness in responsibility of officials, which in turn leads to evasion of responsibilities and lack of clear standards of evaluation (Nonet, Selznick and Kagan 2001: 74-75). Fu and Cullen (2011) similarly note the tendency for traditional mediation in China to give rise to opportunities for party-pressure, corruption and lack of enforcement, accountability and transparency.

In seeking to overcome the real dangers of subordination of law to politics or caprice as identified by critical legal studies scholars (Kelman 1987; Gordon 1994), responsive law 'presumes that purpose can be made objective enough and authoritative enough to control adaptive rule making' (Nonet, Selznick and Kagan 2001: 77).

In the context of responsive law, claims of right are understood as opportunities for uncovering disorder or malfunction and hence may be valued as administrative resources... Legal energies should be devoted to diagnosing 
institutional problems and redesigning institutional arrangements. New modes of supervision, new ways of increasing the visibility of decisions, new organizational units, new structures of authority, new incentives - these are the characteristic remedies of purposive law (Nonet, Selznick and Kagan 2001: 106-107).

Similar to the problem solving aim of mediation, responsive law is seen as:

a problem-solving, facilitative enterprise that can bring to bear a variety of powers and mobilize an array of intellectual and organizational resources (Nonet, Selznick and Kagan 2001: 109).

Rather than coercion, it seeks for a positive search for alternatives, (e.g. incentives, self-sustaining system of obligations) it also aspires to civil morality: a 'morality of cooperation' and participation and access is enlarged by integration of legal and social advocacy (Nonet, Selznick and Kagan 2001: 16). It is described as a form of sociological jurisprudence according to which legal institutions would weigh all the social facts before proceeding to the application of law (Nonet, Selznick and Kagan 2001: 73). It 'strives to search for implicit values in rules and policies' (Nonet, Selznick and Kagan 2001: 79).

The two fundamental presuppositions underlying the aspiration of responsive law are participation and civility. With respect to participation, 'a responsive legal order treats social interests as objectives of moral concern, and recognizes that the vitality of social order comes from below' (Nonet, Selznick and Kagan 2001: 16, citing Baldwin and Black). Public participation is essential to achieving these objectives.

A current challenge of responsive law, and one that policy makers and practitioners not only in China but throughout the world seek to address, is the delicate interaction between responsiveness and community morality and civility. Nonet and Selznick speak to the concept of civility as being integral to responsive law. Responsive law seeks to foster civility by encouraging a problem-centered and socially integrative approach to public order crises. Fu and Cullen (2011) note an inverse relationship such that as bureaucratic legal rationality increases, in many cases, persuasive authority in relation to the underlying social roots of conflict diminishes. In many respects, this notion of civility echoes relational theory, which seeks to overcome the dichotomy of individualism and collectivism through seeing the self and other as inherently connected and mutually responsible (Gilligan 1988).

A common critique of responsive law is that it 'operates outside the law therefore is not law' (Humphries 1994; Mnookin 1979). However at the same time, as law itself is increasingly seen as permeable the notion of law as a fixed set of rules is increasingly questioned. Another more pragmatic critique of responsive law is that in general, it demands a larger share of social resources when for example extensive public participation is involved. It could therefore become a 'precarious ideal' of high aspirations but fragmented implementation.

Within China, the struggles inherent with responsive law as well as legal pluralism studies, including the identification of the relevant social norms in the dispute resolution process, and search for clarity regarding appropriate legal rules and obligations, exist 
alongside the continuing desire for a flexible and efficient approach to the resolution of community disputes. Following part one of this paper, part two examines contemporary mediation policy in China which echoes in many respects the goals and challenges of responsive law. In part three, I provide an empirical exploration of the challenges of applying responsive law ideals in practice including the contemporary search for implicit values through the implementation of grass roots mediation in China. Findings from a 10 part open-ended questionnaire administered by the author with 47 Chinese judicial, mediation and legal officials in the summer of 1997 in Changsha, Beijing, and Shanghai, include insights into the changing place of mediation alongside shifting values in China. These findings are presented alongside more recent empirical findings collected in the early part of 2000 that demonstrate areas of continuity as well as changes in the way mediators respond to increased reliance on the rule of law and changing social values.

The findings of this study contribute to the legal pluralism literature by highlighting the dynamics of change within the context of a traditionally unofficial form of law in China and its interface with the official legal system. It does this by examining how contemporary mediators in China draw a distinction between issues that can be handled at the grass roots level of the neighborhood and issues that require formal legal intervention. This process is partly informed by awareness of the changing pulse of the community, knowledge of changing social norms through repeated encounters with local residents and feedback from such encounters. The findings also illustrate the interplay between the official and unofficial systems of law and highlight the overall support for the formal channels of law by local mediators. In addition, contemporary struggles to identify the place and role of mediation in China also reflect the possibilities of responsive law as a contextualized and 'learning mode of legal intervention' as well as its 'precarious idealism.' 


\section{Contemporary Mediation Policy in China}

Community mediation in China, from traditional times to the present, echoes the original aims of the responsive law movement as it seeks to achieve community-based solutions to social conflict. At the same time, like the responsive law movement, it faces the challenges of a 'precarious idealism' as individuals increasingly express a desire for outcomes that go beyond compromise solutions. In recent times, with the renewed emphasis on mediation in greater China, legal scholars continue to puzzle over how the practice of mediation in China may overcome existing challenges (Wang 2009; Guo 1986). One example of such challenges is the desire for greater accountability and clarity as to the underlying values and principles relevant to the effective resolution of disputes (Fu and Cullen 2011).

Mediation has always been a key mechanism for resolution of disputes in China (Cohen 1966). Community mediation in traditional China had both cultural and functional origins. Key Confucian ideologies such as the importance of cooperation, social ordering (Lubman 1967) and maintaining harmonious relationships (Chow 2002) has existed alongside a general orientation toward the avoidance of lawsuits. Today, people's mediators are expected to identify and mediate conflicts that, if left unresolved, could escalate into full-scale public dissatisfaction or 'large group incidents' (quntixing shijian) disrupting social stability (Halegua 2005).

'Mediation', generally understood as a form of facilitated decision-making (Folberg and Taylor, 1984) and 'conciliation,' a process by which a third party intervenes to offer suggested outcomes (Schwarcz 2010), have often been viewed as distinct, although pragmatic overlap may occur based on careful assessment of party needs (Love 1997). Mediation, in the Chinese context, is essentially synonymous with conciliation. ${ }^{3}$ Therefore, in the translated versions of the Civil Procedure Law of the People's Republic of China ("Civil Procedure Law"), the chapter for mediation/conciliation ("调囵") ${ }^{4}$ is translated as "mediation"

As China entered the reform era, a series of regulations to improve and provide greater structure to the community mediation system were introduced in 1989. In particular, the theme of the 1989 regulations was 'mediation based on law' and changes were made to incorporate legality into the system, including stipulations for mediators to possess a degree of legal knowledge, and perform their work in conformity with the law, statutes, rules, regulations and policies of the state' (Halegua 2005 citing Glassman 1992).

Mediation in China can be divided into three categories: mediation supervised by the people's court, mediation supervised by an arbitral tribunal and mediation without the supervision of a court or arbitral tribunal (He and Zeng 2011a). According to the Several Opinions on Establishing and Improving the Resolution System for Disputes by Linking Litigation and Non-litigation Cases, issued by the Supreme People's Court, typical forms of extra-judicial mediation include: people's mediation,

\footnotetext{
${ }^{3}$ Ibid

${ }^{4}$ Chapter 8, 1991 Civil Procedure Law of the People's Republic of China

${ }^{5}$ See http://www.lawinfochina.com/display.aspx?lib=law\&id=6459

${ }^{6}$ See http://en.chinacourt.org/public/detail.php?id=2694
} 
commercial mediation, administrative mediation, employment dispute mediation and industry mediation.

While there is currently no unified legislation on mediation, the relevant provisions are included through various laws, regulations and rules (He and Zeng 2011a). The most important documents regulating mediation are summarized in Appendix 1. They include, (a) the Civil Procedure Law of the People's Republic of China (the 'Civil Procedure Law'), (b) the 2010 People's Mediation Law of the People's Republic of China (also known as Law of the People's Republic of China on Civil Mediation) (the 'People's Mediation Law'), and (c) provisions/opinions of the Supreme People's Court.

\section{A. Civil Procedure Law}

The original Civil Procedure Law, enacted in 1991, which limited in some respects the judicial emphasis on mediation ( $\mathrm{Fu} \mathrm{1996),} \mathrm{has} \mathrm{an} \mathrm{entire} \mathrm{chapter} \mathrm{dedicated} \mathrm{to}$ articles regarding the practice of mediation (Chapter 8, Articles 85-91, Appendix 2). ${ }^{7}$ The law underwent a number of amendments in $2007,{ }^{8}$ but it appears there was no change to chapter 8 on mediation. ${ }^{9}$

As recently as 31 August 2012, the National People's Congress ('NPC') passed a further amendment to the Civil Procedure Law, which is set to take effect from 1 January 2013. ${ }^{10}$ Whilst no changes have been made to the 7 provisions on mediation in the previous version, additions have been made to formalize mediation as the first mechanism for resolving certain disputes, to protect the integrity of mediated agreements, to allow litigants to apply for enforcement of extra-judicial mediated agreements by the courts provided that the agreement is filed with the courts within 30 days of the agreement, and to empower a civil court to, after investigation, enforce the agreement or require the parties to mediate again if the civil court finds the agreement unlawful. In addition, there were suggestions regarding the supervision of the courts to address the problem of collusion between certain litigants and mediation authorities. ${ }^{11}$ As several amendments in relation to class suits, litigants' rights, and small claims $^{12}$ were made or added to earlier sections, the 7 identical articles on mediation are moved back from 85-91 to 93-99.

\section{B. People's Mediation Law}

\footnotetext{
${ }^{7}$ See World Intellectual Property Organization ('WIPO'), Civil Procedure Law (1991). Available at http://www.wipo.int/wipolex/en/details.jsp?id=850 (last accessed on 17 March 2013).

${ }^{8}$ See WIPO, Civil Procedure Law (2007). Available at:

http://www.wipo.int/wipolex/en/details.jsp?id=6033 (last accessed on 17 March 2013).

${ }^{9}$ An initial crosscheck of the two versions (1991 \& 2007) indicates no apparent difference in the law.

${ }^{10}$ Xinhua, 'China amends civil procedure law following third reading' (31 August 2012). Available at http://news.xinhuanet.com/english/china/2012-08/31/c_131820062.htm (last accessed on 17 March 2013).

${ }^{11}$ See the Chinese Government Official Portal, quoting from Xinhua (31 August 2012). Available at http://english.gov.cn/2012-08/31/content_2214483.htm (last accessed on 17 March 2013). For the Chinese version of the amendments, see http://www.gov.cn/flfg/2012-09/01/content_2214662.htm (last accessed on 17 March 2013).

${ }^{12}$ For changes in these areas of the Civil Procedure Law, see http://www.bjreview.com.cn/nation/txt/2011-11/28/content_408376.htm (last accessed on 17 March 2013).
} 
The People's Mediation Law' aims to bring mediation to 'everyone in China, to provide an alternative which can help them resolve everyday disputes at the grassroots level, without having to go to court ${ }^{, 13}$.

The People's Mediation Committee is established by law as the legitimate organization to resolve everyday disputes, and sets down the procedure for establishing such organizational structures within local committees ${ }^{14}$. The law further provides that governments at county levels and above shall provide financial support for mediation work ${ }^{15}$. Very importantly, the law provides that mediated agreements be legally binding and enforceable by the local courts ${ }^{16}$.

\section{Other laws: Provisions of the Supreme People's Court}

The Supreme People's Court, in a series of judicial interpretations, has steered particular socially significant cases towards mediation, with or without a litigant's consent (Fu and Cullen 2011). In 2002, policy reforms were adopted through the issuance of the 'Three Documents' by the Supreme People's Court ('SPC') and the Ministry of Justice ('MoJ') (Nonet, Selznick and Kagan 2001). The most significant document was the Judicial Interpretation issued by the SPC on 5 September 2002 regarding the legal effect of mediation agreements (Nonet, Selznick and Kagan 2001). Article 1 of the Judicial Interpretation states that an agreement reached through people's mediation, on which the parties have affixed their signatures or seal, is a civil contract and cannot be arbitrarily changed or terminated. While, in reality, a small number of people's mediation cases reach a formal agreement (Peng 2005), ${ }^{17}$ the interpretation has generally lead to greater weight being given to mediated agreements (Peng 2005). ${ }^{18}$

In order to strengthen the enforcement of mediated agreements (He and Zeng 2011b), as early as 2004, the Supreme People's Court issued the 'Provisions about Several Issues Concerning the Civil Mediation Work of the People's Court', which introduces a judicial confirmation mechanism (He and Zeng 2011b). This Order standardized formal guidelines on community mediation procedures including the provision of details on how mediators are to accept cases, (Article 20), a one-month time limit on the mediation of cases (Article 33) and an outline of the rights and obligations of the parties (Articles 6 and 7) (Nonet, Selznick and Kagan 2001). The Several Opinions issued in 2009 further affirmed the legal framework of judicial confirmation, and the

\footnotetext{
${ }^{13}$ See ADR Resources, 'China enacts People's Mediation Law' (29 August 2010). Available at http://adrresources.com/adr-news/747/china-enacts-peoples-mediation-law (last accessed on 17 March 2013).

${ }^{14}$ See ADR Resources, 'China enacts People's Mediation Law' (29 August 2010). Available at http://adrresources.com/adr-news/747/china-enacts-peoples-mediation-law (last accessed on 17 March 2013).

${ }^{15}$ See ADR Resources, 'China enacts People's Mediation Law' (29 August 2010). Available at http://adrresources.com/adr-news/747/china-enacts-peoples-mediation-law (last accessed on 17 March 2013).

${ }^{16}$ See ADR Resources, 'China enacts People's Mediation Law' (29 August 2010). Available at http://adrresources.com/adr-news/747/china-enacts-peoples-mediation-law (last accessed on 17 March 2013).

${ }^{17}$ According to the author's interviews, of the 8000 people's mediation processes in sample District A of Shanghai, only $5 \%$ led to a formal agreement.

${ }^{18}$ In particular, this was argued during the interview with head of section $\mathrm{Z}$ of the legal office of sample District A of Shanghai, December 11, 2002.
} 
Several Provisions issued in 2011 offers even more detailed regulations on proceedings, time limits, and jurisdiction of the court (Nonet, Selznick and Kagan 2001). ${ }^{19}$ Judicial confirmation of the mediation agreement aims at improving the efficiency of mediation, conserving court cost and resources (Nonet, Selznick and Kagan 2001). In 2004, China's courts upheld over $87 \%$ of the 21,651 mediated agreements that parties sought to enforce (Zhongguo Falu Nianjian She 2004: 200).

In addition to judicial confirmation, delegated mediation, affirmed by the Supreme People's Court in the Provisions on Mediation in 2004, also serves as an impetus for expanding extra-judicial mediation. Article 3 of the Provisions on Mediation provides that the courts may invite institutions, enterprises or organizations, which have the expertise, professional and social knowledge and experience, to bring about and assist in the mediation work of the Civil Procedure Law. If a mediation agreement is reached, the people's court is required to confirm it according to the law.

Commercial mediation is the best example of this change. The CCPIT Conciliation Center issued 'Guidance on Improving the Connection between Mediation and Litigation with the People's Court' to echo the implementation of the Several Opinions. According to the CCPIT's statistics, since the Several Opinions came into force, the number of accepted cases of the first half of 2010 has already exceeded the caseload for the entire year of 2009. Observers have noted that the cooperation between the people's courts and mediation institutions has strengthened the parties' 'faith and trust in resolving their disputes by mediation' (Zhongguo Falu Nianjian She 2004: 200).

\section{People's Mediation Committees}

People's Mediation Committees ('PMCs') are the basic units responsible for carrying out community mediation in Chinese society. PMCs mediate disputes under the guidance of the people's government and people's basic courts.

The Constitution of China specifically provides for the establishment of PMCs under the grassroots autonomous organizations of Residents Committee ('RC') ( $j u$ wei hui) and Villagers Committee ('VC') (cun wei hui $)^{20}$. Enterprises and public institutions may establish PMCs if necessary ${ }^{21}$. The People's Mediation Law endorses the PMC as the legal organization to resolve everyday disputes and sets down the procedure for the formation of $\mathrm{PMCs}^{22}$. A PMC is composed of 3 to 9 members and may have one director and should include female members ${ }^{23}$. The members of PMCs formed under RCs or VCs are selected at the villagers' meeting or residents' meeting while the members of PMCs of an enterprise or public institution are selected by the employee's assembly, the employees' representative meeting or the labor union, each with a term of office of three years ${ }^{24}$. Typical PMC's have generally included the

\footnotetext{
${ }^{19}$ See also: Provisions of the Supreme People's Court on Issues Concerning the Process of Judicial Confirmation of People's Mediation Agreements Fa Shi [2011] No. 5

${ }^{20}$ Article 111, Constitution of People's Republic of China

${ }^{21}$ Article 8, the People's Mediation Law

${ }^{22}$ See NPC of the People's Republic of China, 'Chinese legislature passes People's Mediation Law' (30 August 2010). Available at http://www.npc.gov.cn/englishnpc/news/Legislation/201008/30/content_1593770.htm (last accessed on 29 July 2012)

${ }^{23}$ Article 8, the People's Mediation Law

${ }^{24}$ Article 9, the People's Mediation Law
} 
leader of the RC, the Party Secretary of the residential community, the members of the RC responsible for culture and education, the heads of organizations and police officers (Peng 2005). The PMC hires the people's mediators, who are required to be adult citizens, impartial, decent and dedicated to people's mediation. They are also required to possess a certain level of education, policy understanding and legal knowledge ${ }^{25}$.

The work of PMC extends beyond passive supervision of the mediation of disputes. They are expected to take the initiative to gather necessary information, anticipate disputes among various communities while finding a compromise to these disputes and bring the settlement to the community's attention (Shanghai Justice Bureau 2000: $1)$.

PMCs often work with residents in each building who serve as 'building heads' (louzhang) or 'informants' (xinxiyuan) who may be organized into small mediation groups (tiaojie xiaozu) (Peng 2005). These informants or groups are responsible for monitoring disputes within their buildings and reporting such disputes to their respective PMCs. Informants are often involved in the mediation processes too as they are considered to be more familiar with the parties and the issues under contention (Nonet, Selznick and Kagan 2001).

The People's Mediation Law states that PMCs should work under the direction of the administrative departments of justice, the local government, and the grassroots people's courts ${ }^{26}$. This supervisory work is assumed by judicial assistants ('JAs'). JAs are expected to respond to the PMC's request for instructions and assistance in mediation and to party complaints (Nonet, Selznick and Kagan 2001). They are also responsible for the inspection of mediation agreements and rectifying any violation of the law, regulations or administrative rules and policies (Nonet, Selznick and Kagan 2001). The degree of involvement of JAs in the community mediation process can vary greatly from limited involvement to primary oversight of the mediation process (Nonet, Selznick and Kagan 2001). ${ }^{27}$ The lack of independence from the government is seen as one of the major problems faced by community mediation in China (Halegua 2005 quoting Ji 2004).

It has been suggested that the solution may be found in the establishment of private mediation workrooms. For example, the Jiangsu Street Office in Shanghai's Changning District contracted with Li Qin, a famous local mediator at RMB 120,000 to set up a mediation workroom (Halegua 2005 quoting Ji 2004). It mediated at least $40 \%$ of all conflicts in the subdistrict with no less than a $95 \%$ success rate and at least $90 \%$ of the difficult cases with no less than an $80 \%$ success rate. The workroom also reviews all written agreements by the PMCs to ensure their clarity and compliance with the law. The sourcing out of mediation work to professional workroom

\footnotetext{
${ }^{25}$ Article 13, the People's Mediation Law

${ }^{26}$ Article 5, the People's Mediation Law

${ }^{27}$ This happens frequently with collective disputes relating to work enterprise units and where residents are forced out of their homes. Residents prefer to the seek help from JAs appointed by the Government. JA's generally possess more legal knowledge, experience and mediation skills than RC members. The parties also generally believe JA's are more impartial when solving local disputes. Nevertheless some have voiced concerns that the overzealous involvement of JA's and suggest that an alternative approach might be the establishment of private mediation workrooms.
} 
mediators ensures the quality of mediation processes and maintains the separation of community mediation from government intervention.

Despites the merits of the system, the model requires substantial funding by the local government. Under the People's Mediation Law, PMCs may not charge fees for the mediation of disputes among the people (Article 4, the People's Mediation Law). While the People's Mediation Law stipulates that governments at county level and above shall provide financial support for mediation work (Article 8, the People's Mediation Law), few regions other than affluent Shanghai have spare resources to hire professional mediators for the job.

The People's Mediation Law further regulates the content and enforceability of the mediation agreement. In the event that parties believe it unnecessary to make a written mediation agreement, the people's mediators are required to note down the contents of the oral agreement ${ }^{28}$. Both written and oral mediation agreements are legally binding ${ }^{29}$. The parties may also jointly apply to the people's court for judicial confirmation within 30 days after the mediation agreement becomes effective $\mathrm{e}^{30}$. If one party refuses to perform or fulfill the mediation agreement, the other party may apply to the people's court for enforcement ${ }^{31}$.

Another notable aspect of the Mediation Law is the emphasis on the rights enjoyed by the parties to a dispute before and during the mediation process. Parties retain the ultimate right to refuse to settle the dispute by mediation. If the parties choose to accept mediation, they are entitled to several rights, including the right to select or accept the people's mediators; accept or refuse the mediation process or require the termination of mediation, require that the mediation be made public or private and most importantly 'reach a mediation agreement on free will' ${ }^{32}$. In the event that the parties are unable to reach a mediation agreement, the people's mediators are required to terminate the mediation process and allow the parties to resort to other dispute resolution resources by arbitration, administrative or judicial means ${ }^{33}$. This emphasis on the voluntariness of the community mediation process is particularly important to prevent coerced settlement or deprivation of the legal rights of the parties in a dispute.

\section{China's 'Harmonious Society' Policy}

Recent mediation law reforms in China can also be viewed in the context of China's harmonious society policy. The concept of 'harmonious society' (hexie shehui), first introduced as one of five governing principles of the Chinese government at the Fourth Plenum of the $16^{\text {th }}$ Central Committee of the Communist Party of China ('CCP') in September $2004^{34}$ includes within it the aspiration toward the development of a 'fine tuned ... system' to handle internal contradictions and advance the goal of 'common prosperity' (gongtong fuyu) (Chan 2009). Chinese President Hu Jintao

\footnotetext{
${ }^{28}$ Article 28, the People's Mediation Law

${ }^{29}$ Article 31, the People's Mediation Law

${ }^{30}$ Article 30, the People's Mediation Law

${ }^{31}$ Article 33, the People's Mediation Law

${ }^{32}$ Article 23, the People's Mediation Law

${ }^{33}$ Article 26, the People's Mediation Law

${ }^{34}$ See: CPC Encyclopedia, 'Harmonious Society'. Available at: http://www.cpcchina.org/201009/16/content_13918117.htm (last accessed on 9 September 2012).
} 
reiterated the government's commitment to the policy at the opening ceremony speech of a high-level CCP seminar in 2005. President Hu claimed that as China's per capita value of gross domestic production ('GDP') exceeded US\$1,000, it had reached a crucial stage of socioeconomic development where the potential for crime and corruption to threaten social stability and harmony had increased (Chan 2009). He explained that a harmonious society should be built based on sustained, rapid and coordinated economic growth, development of rule of law, ethical development, and the establishment of 'a fine-tuned social management system' to handle 'internal contradictions' meaning neighborhood or workplace disputes ${ }^{35}$.

The doctrine of 'harmonious society' was formally endorsed by the CCP upon the adoption of the 'Resolution on Major Issues Regarding the Building of a Harmonious Society' at the Fourth Plenum of the $16^{\text {th }}$ Central Committee of the CCP on October $2006{ }^{36}$ The goals of promoting harmonious society include the principle of administering the country according to law; guaranteeing respect for people's rights and interests; narrowing the gap between urban and rural development and between different regions. ${ }^{37}$

The People's Mediation Law, which came into force in January 2011, is a prime example of legislative reforms targeted to address social disputes. The Mediation Law encourages community mediation, as an important means to resolve social disputes before they escalate into mass conflicts.

At the same time, the Supreme People's Court has recognized the role of mediation in the establishment of a harmonious society. In the 'Several Opinions of the Supreme People's Court on Further Displaying the Positive Roles of Litigation Mediation in the Building of a Socialist Harmonious Society' ${ }^{38}$ published in 2007, the Court expressed the view that the people's courts are responsible as trial organs of the state to 'increase harmonious elements and decrease disharmonious elements' when handling social contradictions and disputes through litigation and mediation. A guideline on mediation was subsequently released in June 2010, which requires local courts to understand the 'unique advantage and important value' of mediation in addressing social conflicts, maintaining social stability and promoting a harmonious

\footnotetext{
${ }^{35}$ People's Daily Online, 'Building harmonious society crucial for China's progress: Hu' (June 2005). Available at: http://english.people.com.cn/200506/27/eng20050627_192495.html (last accessed on 9 September 2012).

${ }^{36}$ International Department of Central Committee of CPC, 'Resolution on harmonious society' (10 October 2006). Available at: http://www.idcpc.org.cn/english/events/061019.htm (last accessed on 9 September 2012).

${ }^{37}$ Ibid. The implementation of the 'harmonious society' doctrine can be demonstrated by China's regulatory shift from economic matters to social issues. Chairman Wu Bangguo of the NPC specifically called for a need to enact laws on social programs to provide a solid legal foundation for a harmonious society. According to the Chinese Academy of Social Sciences' researcher in law, Li Lin, after the $10^{\text {th }}$ NPC took office, new legislations on social issues have increased to $20 \%$ at the NPC level and up to $40 \%$ at the provincial and lower levels, compared to only 2 to $6 \%$ prior to the introduction of the policy. For further, see People's Daily Online, 'Towards harmonious society through rule of law' (10 March 2008) Available at: http://english.people.com.cn/90001/90776/6369630.html (last accessed on 9 September 2012).

${ }^{38}$ The document is available at:

http://www.lawinfochina.com/display.aspx?lib=law\&id=5930\&EncodingName=big5 (last accessed on 9 September 2012).
} 
society. ${ }^{39}$ It also encouraged expansion of the scope of mediation from civil to minor criminal cases and administrative cases. ${ }^{40}$

Recent changes to China's mediation law have aimed at formalizing the mediation process, assuring party autonomy and providing a mechanism for responding to social conflicts before they escalate. In practice, however, mediation is becoming a 'precarious ideal' as rapidly changing social values and aspirations alter how individuals view appropriate rules and processes and as a result undermine the efficacy of mediation in resolving disputes. This will be discussed in greater detail in the sections that follow.

\footnotetext{
${ }^{39}$ China Daily Online, 'Mediation can help settle rising disputes' (20 June 2010). Available at http://www.chinadaily.com.cn/china/2010-06/29/content_10031522.htm (last accessed on 9 September 2012).

${ }^{40}$ China Daily Online, 'Mediation can help settle rising disputes' (20 June 2010). Available at http://www.chinadaily.com.cn/china/2010-06/29/content_10031522.htm (last accessed on 9 September 2012).
} 


\section{Mediator Perspectives}

The aforementioned reforms in the mediation laws and regulations and the changes in social and economic values have profoundly impacted the role and practice of mediation in China. Based on interviews conducted in 1997 and empirical data collected in early 2000, this section examines the changes in the place and practice of mediation by firstly inspecting the statistical data in relation to mediation in China, secondly understanding mediation practice through the mediators' experiences and perspectives, and finally examining the impacts of the recent legal reforms on the process and (perceived) efficacy of mediation.

\section{Chinese Mediation Statistical Data}

In recent years, while the percentage of total mediated cases handled within Chinese courts has declined significantly, from more than $90 \%$ in the early 1980 's, to $29 \%$ in 2007 (see Table I), the total overall number of mediated cases handled by the courts has experienced both a decline and a resurgence ( $\mathrm{Fu}$ and Cullen 2011) from a total of 555,585 in 1993 to 330,313 in 2001 then 716,882 in 2007.

TABLE 1: DOMESTIC CONTRACT DISPUTES ACCEPTED FOR INCOURT MEDIATION AND LITIGATION IN THE PRC, 1986-2007 ${ }^{\mathbf{4 1}}$

\begin{tabular}{|l|l|l|l|}
\hline YEAR & $\begin{array}{l}\text { CASES } \\
\text { MEDIATED }\end{array}$ & $\begin{array}{l}\text { TOTAL } \\
\text { CASES }\end{array}$ & $\begin{array}{l}\text { PERCENT } \\
\text { CASES } \\
\text { MEDIATED }\end{array}$ \\
\hline 1985 & NA & NA & $90 \%$ \\
\hline 1986 & NA & 322,153 & NA \\
\hline 1987 & NA & 332,496 & NA \\
\hline 1988 & 355,524 & 467,872 & $75.9 \%$ \\
\hline 1989 & 473,128 & 634,941 & $74.51 \%$ \\
\hline 1990 & 384,810 & 543,613 & $70.78 \%$ \\
\hline 1991 & 330,313 & 516,507 & $63.95 \%$ \\
\hline 1992 & 367,252 & 650,601 & $56.44 \%$ \\
\hline 1993 & 555,585 & 894,410 & $62.11 \%$ \\
\hline 1994 & 587,825 & 971,432 & $60.51 \%$ \\
\hline 1995 & $\mathrm{NA}$ & $1,184,377$ & $\mathrm{NA}$ \\
\hline $2001^{43}$ & 328,279 & $1,062,302$ & $30.90 \%$ \\
\hline $2002^{44}$ & 617,769 & $2,266,695$ & $27.25 \%$ \\
\hline $2003^{45}$ & 602,251 & $2,266,476$ & $26.57 \%$ \\
\hline $2005^{46}$ & 646,934 & $2,265,362$ & $28.56 \%$ \\
\hline $2006^{47}$ & 634,672 & $2,240,759$ & $28.32 \%$ \\
\hline
\end{tabular}

\footnotetext{
${ }^{41}$ See Zhongguo Falu Nianjian (Law Yearbook of China) (Beijing: Zhongguo Falu Nianjian She, 1983-1995); Statistics derived from the Chinese Legal Yearbook on the number of cases handled by mediation as compared with the number handled by litigation, indicate a significant decline in the overall percentage use of mediation over the past 30 years. This sharp decline has existed alongside an increase in the total overall number of mediated cases in recent years.

42 See Palmer (1987: 223).

${ }^{43}$ See Zhongguo Falu Nianjian She (2002: 777).

${ }^{44}$ See Zhongguo Falu Nianjian She (2004: 654).

${ }^{45}$ See Zhongguo Falu Nianjian She (2004: 674).

${ }^{46}$ See Zhongguo Falu Nianjian She (2006: 486).
} 


\begin{tabular}{|l|l|l|l|}
\hline $2007^{48}$ & 716,882 & $2,463,775$ & $29.10 \%$ \\
\hline
\end{tabular}

Many have attributed the dramatic drop in the percentage of cases mediated in 1992 to the new Civil Procedure Law in the PRC, which altered the requirements for using mediation prior to in court litigation. Before 1991, disputants would often be required to mediate a case prior to litigation. However, the 1991 Civil Procedures Law removed the focus on mediation and simplified the procedures for in-court litigation. The reduction in the use of mediation during this time can also be attributed to new perspectives on cases appropriate for mediation and litigation and increased numbers of 'litigable' cases.

While the percentage of mediated cases continues to decline, new laws and directives introduced in the early 2000's have revived the emphasis on mediation, which is reflected in the rise in the total number of mediated cases beginning in 2002.

\section{Perceptions of the Decline of Mediation and Support for Litigation: Interview Data}

Based on the 1997 interview data ${ }^{49}$ and the empirical findings in early 2000, this section explores local mediators' perceptions of the changing status of mediation, their receptivity/aversion to legal development, and their perspectives of the types of cases appropriate for mediation, and those appropriate for litigation.

According to the interviews and empirical findings, whilst traditional values and ethics, such as yielding, filial piety, respect for authority and for the elderly, the preservation of relationships, harmony, the internal handling of private affairs, continued to be heavily relied upon in resolving 'conflicts among the people', these same values and ethics are losing their once prominent role and are increasingly regarded as irrelevant by a society undergoing rapid 'modernization'. Further, responses indicate that mediators have demonstrated an enthusiastic receptivity and even a desire to participate in the promotion of the spread of the rule of law. Such changes in perceptions and values, both in the local communities and among the mediators, are shifting the focus of mediation in China.

\section{The role of traditional values in mediation}

In relation to the first theme, twenty-seven mediators, out of the forty-seven interviewed, indicated that mediation was regarded as a means to promote harmony as it emphasizes compromise, harmony among the collective and the preservation of relationships. Moreover, they would rely on traditional values when resolving disputes because these values serve as the benchmark distinguishing right from wrong. A mediator found it helpful to criticize the wrong doer based on these values, so as to compel one party or another to bend, to see his/her 'error', and eventually to change his/her 'erroneous ways'.

\footnotetext{
${ }^{47}$ See Zhongguo Falu Nianjian She (2007: 593).

${ }^{48}$ See Zhongguo Falu Nianjian She (2007: 616).

49 The interviews took the form of a 10 part open-ended questionnaire administered by the author with 47 Chinese judicial, mediation and legal officials in the summer of 1997 in Changsha, Beijing, and Shanghai.
} 
One mediator of a neighborhood committee in Beijing commented that in approaching a conflict, he would first rely on ethical principles to try to resolve the dispute. But if that didn't work, he would then resort to legal principles and measures. In handling a divorce, for example, he might emphasize the bond between parents and child, the vital role of the family in Chinese society, the duty of parents to care for their children, or the destructive nature of separation, to persuade the couple to stay together. The same is used when mediating a dispute between friends:

The judge may say: if you accept the ruling now, the case will be finished with, if not, you will have to go through the hassles of court. You are good friends. Though you have a problem now, you have a long future together as friends; it is best to resolve this simply and quickly...

Another long standing value that appears to remain relevant is the importance placed on privacy and confidentiality. The 1997 interviews indicate the continuing relevance of the idea that one's individual private affairs be best left private. According to a traditional proverb, 'to hang out one's laundry is to have the [unpleasant smell] fly in a hundred directions'. To date, mediators continue to emphasize the importance of not involving 'outsiders'. Because mediation provides an environment that is private, small, and in familiar territory (often in the disputants home, or a close by office of the residence committee) many are persuaded to resolve the case there and then:

If the conflict is within the same family, I will come in and calm the parties down, their incentive is that they don't want to involve more people, so they'll calm down and deal with the issue.

In other conflicts, such as those between elders and youth, the concept of deference, yielding, and piety are still often invoked in resolving a dispute. The reliance on these traditional Confucian values, as noted by interviewees in 1997 continued to assist parties to resolve certain types of conflict:

The other day there was a conflict between an elderly gentleman and a young man. The elderly gentleman accidentally brushed against the young man, and the young man then shoved him. After a heated exchange, I reminded the young man of the virtue of respecting elders, while I told the gentleman to let some things pass for the sake of resolution, and the issue was resolved successfully.

\section{The impacts of changing social and economic values}

It was observed, both in the 1990s and the 2000s, that 'older residents are far more likely to use the services of the PMC' (See Haluega 2005, citing Yang 2000). According to one mediator who was based in Shanghai, although only $23 \%$ of residents in the subdistrict where she worked were senior citizens, it was estimated that $60 \%$ of mediations in that subdistrict involved at least one such citizen (Haluega 2005). The difficulty begins to arise, however, when these values begin to be questioned by the younger generation. As one of the mediators commented, "elderly people are much more responsive to our traditional ethics, however the young have a harder time responding to these ideals'. 
The shift away from traditional values, in certain circumstances, can be seen in the increased frustration experienced by many law officials who complain that these traditional values seem to fall on deaf ears. One judge noted his frustration that:

Sometimes I hear, 'oh, those ideas are too old fashioned!' It becomes difficult for me to persuade them to accept the settlement agreement. For example in a recent divorce case, I was trying to persuade both parties to avoid divorce considering the bond between them and their child...etc. but they decided to litigate the case instead and get a divorce.

Such shifts in values, as many mediators have noted, have contributed to the movement toward increased focus on litigation. A 1997 empirical study conducted by the China Social Investigation Office similarly found, after surveying 1,500 Chinese citizens on their legal knowledge and views, that 'negative results which harm parties' interests may be produced if mutual understanding and concession is overemphasized and when the basic principle of mediating in line with the law is forgotten'.

Some judges are aware of current social changes, and desire to persuade disputants to accept their ruling, might suggest that, 'if a couple is clearly not happy together and face a tremendous amount of pressure from their family to stay together, I may [support their decision] to get a divorce'.

These current shifts in values and traditions have been observed as affecting the mediation style and in some cases causing a movement away from traditional forms of mediation itself. According to one judge, '[social] values must change when they do not fit the current context'. For example, because engagement is no longer considered a binding agreement, this principle is less effective as a basis for settling a dispute over a breech of engagement. One professor of History and Literature at Hunan Normal University noted that due to these changes in values, a style of mediation which relies on the conciliation of cases according to traditional values itself is being threatened:

[Traditional mediation] is founded upon the context of the neighborhood as well as a core set of traditional values that are rapidly changing. Here we all stop to say hello, we greet one another on the road, we buy vegetables together. But now as the country is changing, people move to the cities, move jobs, move into tall impersonal apartment complexes, our neighbor to neighbor interaction is decreasing. We are having a more independent lifestyle, while traditional bonds between people are becoming strained. The context upon which mediation is based is changing.

One lawyer agreed with this notion, adding that as economic and social changes are taking place, the traditional values underlying mediation are also changing:

Especially with the growth of economic prosperity, and the open door, those values underlying mediation are being called to question, a void is emerging with the confusion of those values, so now there is greater focus on law. 
These observations are echoed by more recent empirical findings:

Today's mediators often lack such personal ties with the parties, and failing to command their deference, must provide convincing legal or other reasons to persuade them... One Beijing resident explained that while growing up, he would certainly do whatever he was told by the community mediator: 'She was friends with my grandfather, how could I not listen to her?' (Halegua 2005, recounting the personal interview with Director Zheng Zhong at Xuanwu District Public Security Mediation Centre, Beijing, 2 June 2005).

In addition, more recent empirical findings have echoed the observation that an increased sense of isolation due to changing socio-economic conditions and living arrangements has contributed to the declining efficacy of traditional approaches to mediation:

Some argue that the increased wealth of urban residents has decreased the number of neighbour and family conflicts traditionally dealt with by the community PMCs. For instance, Beijing PMC Director Wang, who has been doing such work for nearly 25 years, explains that residents who would previously refuse to fix the leaky pipes that dripped into their neighbour's apartment can now afford to have them repaired. Similarly, whereas Director Wang had the grueling task of helping wives find ways to cohabitate with their mother in laws in the past, nowadays the husband can buy a new apartment for him and his wife to move into, the relationship need not even be reconciled. In explaining why from the 1970s to early 1990s she mediated 100 cases annually ('every day there was something') and in 2001 she mediated just a single case, Director Wang also sees a change in residents' attitude and lifestyle: 'In the past, nobody had anything, so they would argue and fight over the littlest things; but today, people are more focused on their work, some only come home to eat dinner and sleep. They barely know or talk with their neighbors, so how can they get into a dispute with them?' (Halegua 2005, recounting the personal interview with Director Wang at the Keqing RC, Beijing, 7 January 2005).

\section{Impact of Legal Reform on Mediation Work}

In the context of shifting social values, interviewees in 1997 indicated that the majority, or $80 \%$ of mediators, see legal development as having a beneficial impact on the work of mediators in particular. This viewpoint has remained stable over the past 16 years, as indicated by recent empirical findings.

Most, if not all mediators, expressed support for strengthening of the rule of law in China. Forty out of the forty-seven mediators interviewed saw the development of the rule of law as having a positive effect on their mediation work. When asked to describe the most important qualities of an effective mediator, the majority of respondents reported that 'a clear and thorough understanding of the law' was among the most important qualities.

In particular, mediators were enthusiastic about what they saw as increased objectivity and legitimacy due to the spread of the rule of law. It seemed to them that 
emerging legal codes and regulations would assist their work by making once negotiable infractions less negotiable.

Specifically mediators observed that new regulations assisted their mediation work by defining a set of standards, and legitimizing resolution. In many ways, through this increased clarity of legal boundaries, the need for mediation declined. One mediator noted that:

as a set of clearly defined laws was established, people's respect for legal boundaries increased.

While another noted that:

Because these laws are not coming from individuals but from [legal codes], there is an increased objectivity, and legitimacy to our work.

One mediator, who was also a representative to her district People's Congress, saw that through the establishment of well-defined boundaries, 'deviant' behavior became less 'negotiable'. Whereas, individuals may have once pursued self-help in the absence of clear restraints, new laws have set clear lines as to those actions that are lawful and those that are not.

A woman told me that she was going to take all of her husband's belongings and destroy them because he was cheating. I told her she must think twice before doing something like that, she could go to jail according to such and such regulation-because the law was there I could offer her sound advice, and she accepted it. We need more regulations to create a better livelihood and have to resolve disputes in an institutional manner, that is why we need to resolve disputes according to law.

As a result of increasing clarity of legal regulations since the open door reform in the early 1990s, the rise of commercial and civil disputes among strangers, and the development of dispute resolution mechanisms other than mediation, the number of cases handled by people's mediation committees has steadily declined (Fu and Cullen 2011). However, beginning in 2002, with greater training in relevant legal reforms, and policies pertaining to the voluntary nature and enforceability of mediated agreements, mediation has experienced a partial resurgence (Halegua 2005, citing Zhongguo Falu Nianjian She 1986-2001). While '7.4 million cases were handled by the PMCs in 1990, this number dropped to 5 million by 2000 and fell to just 3.1 million cases in 2002 - roughly $40 \%$ of the 1990 number' (Halegua 2005, citing Zhongguo Falu Nianjian She 1986-2001). This was enhanced by the legal training of mediators and by clarifications regarding the judicial enforceability of mediated agreements. The number of cases handled by PMC's increased from ' 3.4 million in 2002 to 4.49 million in 2003 and up to six million in 2004' (Halegua 2005, citing Zhongguo Falu Nianjian She 1986-2001).

With growing clarity of legal boundaries, community expectations regarding requirements for mediator legal knowledge have likewise expanded. In a follow up study in 2002 of Beijing residents, Ting Wang discovered that $88 \%$ of respondents 'expressed the need for people's mediators to upgrade their legal knowledge' 
(Haluega 2005, citing Wang 2002). This may explain why these respondents, while still preferring to use mediation for solving family and neighbor disputes, far prefer the use of litigation for economic cases involving property or commerce (Haluega 2005, citing Wang 2002). 'Wang's survey also revealed that... 90 per cent of respondents said seeking legal finality would be their primary motivation for filing a lawsuit' (Haluega 2005, citing Wang 2002).

Beginning in 2002, the legal status of mediation agreements was clarified resulting in a significant increase in the enforcement of mediated agreements: 'Official statistics report that the courts upheld 18,895 (over $87 \%$ ) of the 21,651 mediated agreements that parties failed to implement in 2004' (Halegua 2005, citing Zhongguo Falu Nianjian She 2004). According to survey data collected in 2005, 'mediators no longer moan of how the frequent violations of mediated agreements make their work pointless, but speak proudly of the care they take in preparing these agreements because they are upheld by the court (Halegua 2005, citing personal interviews with mediators). Much of this improved clarity regarding the status of mediated agreements can be traced to the 5 September 2002 Judicial Interpretation issued by the SPC that clarifies the legal status of agreements reached through people's mediation. The 'Interpretation has also encouraged mediators to draft more written agreements, of which 70 per cent were reportedly implemented and again, 87 per cent of those brought before the courts were upheld in 2004' (Halegua 2005, citing Zhongguo Falu Nianjian She 2004).

In addition to the increasing enforceability of written mediated agreements after 2002, the growth in peoples mediation committees and private mediation workrooms has likewise expanded: 'The 2002 Provisions call for the establishment of People's Mediation Committee's at the township and subdistrict levels (Article 10) -- where the Judicial Assistants serve. This is generally the highest level in the "mediation web." According to official statistics, 40,000 such committees, comprising 93 per cent of all towns and subdistricts were established by 2003 and handled 1.11 million of the 5.7 million cases processed by PMCs that year' (Halegua 2005, citing Zhongguo Falu Nianjian She 2004). According to a study conducted in 2005, 'as one moves up the "mediation web" from... the PMC to the JA, particularly this last step, the success rate of mediation increases' (Haluega 2005).

In addition to improved enforcement of mediated agreements, people's mediation committees have been reported to have helped prevent the escalation of civil cases, group fights, and suicides: 'An MoJ official reports that each year PMCs prevent over 30,000 suicide cases (involving over 50,000 people) and over 50,000 civil cases from escalating into criminal matters (involving over 120,000 people), as well as stop nearly 100,000 group fights' (Haluega 2005 citing Wang 2005).

In 2005, the provincial government of Hunan implemented a program linking people's mediation, judicial and administrative mediation. The result has been a decrease in the number of civil cases accepted by the people's courts in Hunan province, reportedly declining by a rate of $7 \%$ per year ( $\mathrm{Li}$ and Wang 2009). More than $90 \%$ of disputes are resolved at the grassroots level ( $\mathrm{Li}$ and Wang 2009).

The People's Court of Changsha City established five professional judicial working rooms specializing in Tourism, Community Real Estate, Non-Native Workers, 
Consumer Rights and Interests, and Women's Rights and Interests (Li and Wang 2009). These working rooms provide a space for the judiciary and administrative organizations to work together with disputants to resolve ongoing conflicts.

The following case study of the operation of a mediation workroom in Changsha demonstrates the integration of efforts by local administrative agencies and peoples mediation committees to jointly work to prevent the escalation of existing disputes:

In January of 2008, Mr. Chen, a contractor for the Provincial Highway, was asked by Mr. Lu, a local villager to help him hoist some machinery equipment for his factory for a fee of RMB5000, to which Mr. Chen agreed. During the hoisting process, Mr. Lu's machinery equipment fell and was damaged along with a section of a nearby residence. As a result, Mr. Lu's factory was unable to run as normal. Mr. Lu demanded RMB180,000 in compensation to which Mr. Chen refused. Following Mr. Chen's refusal, Mr. Lu along with some relatives detained Mr. Chen's crane, which resulted in the delay of the construction of the Provincial Bridge.

The Mediation Commission of Miandu Town conducted a joint investigation along with officials from the Township Urban Construction and Land Resources bureau and the People's Mediation Board. They estimated that Mr. Lu's total loss came to RMB110,000.

On 5 January 2008 a mediation was conducted at the Mediation Office of the Township Mediation Commission. Both parties were informed that should they reach an agreement, the result would be a legally enforceable and binding contract. The mediators acknowledged liability on both sides: Mr. Chen was responsible for the damage to Mr. Lu's equipment at the same time $\mathrm{Mr}$. $\mathrm{Lu}$ unlawfully detained the construction equipment thus delaying the bridge construction project. The parties were persuaded to accept a suggested settlement amount of RMB80,000 in compensation to which both parties agreed.

The parties were encouraged to overlook self-interest so as to better serve the country's economic development and to look for the facts without succumbing to local protectionism ( $\mathrm{Li}$ and Wang 2009).

While social values, economic conditions, and community ties are in a state of flux impacting the traditional approach to mediation in China, a new version of mediation is emerging, which is characterized by increased clarity of legal boundaries, heightened community expectations regarding requirements for mediator legal knowledge, clarification of the legal status of mediation agreements, expansion in people's mediation committees and private mediation workrooms, and the use of mediation to prevent the escalation of civil cases (Halegua 2005 citing Wang 2005).

\section{Conclusion:}

In sum, the practice of mediation in China echoes the jurisprudence of responsive law and is currently undergoing a process of redefinition. Traditionally, the practice was heavily influenced by Confucian values and ideologies. But contemporary struggles, 
driven and fuelled by changes in societal values, have led to the decline in the strength of traditional values in facilitating compromises and agreements, thereby creating the needs for new orders and norms that govern and facilitate the practice of mediation.

The findings of this study contribute to the legal pluralism literature by highlighting the dynamics of change within the context of a traditional unofficial form of law in China and its interface with the official legal system. It does this by examining how contemporary mediators in China draw a distinction between issues that can be handled at the grass roots level of the neighborhood and issues that require formal legal intervention. This process is partly informed by awareness of the changing pulse of the community, knowledge of changing social norms through repeated encounters with local residents and feedback from such encounters. The findings also illustrate the interplay between the official and unofficial systems of law and highlight growing support for formal channels of law by local mediators in large-scale and complex cases.

In addition, contemporary struggles to identify the place and role of mediation in China also reflect the possibilities of responsive law as a contextualized and "learning mode of legal intervention' as well as its "precarious idealism." The major challenges faced by the practice of mediation in China, as it is inherent with responsive law, include the identification of relevant social norms in the dispute resolution process, and the search for clarity regarding appropriate legal rules and obligations. The recent reforms and the resulting reorientation of mediation towards 'harmonious civilization' and 'rule of law' therefore appear, as supported by the empirical data, to be appropriate ways to address these challenges and to achieve optimal responsive mediation in action. 


\section{Appendix 1: Laws and Regulations Related to Mediation}

1. National People's Congress and its Standing Committee

\begin{tabular}{l|l|}
\hline Laws and Regulations & Time of Implementation \\
\hline $\begin{array}{l}\text { People's Mediation Law of the People's } \\
\text { Republic of China }\end{array}$ & January 1, 2011 \\
\hline $\begin{array}{l}\text { Civil Procedure Law of the People's } \\
\text { Republic of China }\end{array}$ & April 9, 1991 \\
\hline $\begin{array}{l}\text { Law of the People's Republic of China on } \\
\text { Mediation and Arbitration of Labor } \\
\text { Disputes }\end{array}$ & May 1, 2008 \\
\hline
\end{tabular}

2. Ministry of Justice

Laws and Regulations Time of Implementation

Certain Provisions on the Work of People's Mediation

November 1, 2002

\section{State Council}

\begin{tabular}{|l|l|}
\hline Laws and Regulations & Time of Implementation \\
\hline $\begin{array}{l}\text { Regulations for the Organization of } \\
\text { People's Mediation Committees }\end{array}$ & June 17, 1989 \\
\hline $\begin{array}{l}\text { Measures for Administrative Mediation } \\
\text { over Contract Disputes }\end{array}$ & November 3, 1997 \\
\hline
\end{tabular}

\section{Supreme People's Court}

\begin{tabular}{l|l|}
\hline Laws and Regulations & Time of Implementation \\
\hline $\begin{array}{l}\text { Provisions on the Trial of Civil Cases } \\
\text { Involving the People's Mediation } \\
\text { Agreements (Fa Shi [2002] No. 29) }\end{array}$ & November 1, 2002 \\
\hline $\begin{array}{l}\text { Opinions on Several Issues of the } \\
\text { Application of the Civil Procedure Law of July 14, 1992 } \\
\text { the People's Republic of China }\end{array}$ & \\
\hline $\begin{array}{l}\text { Provisions on Several Issues of the Civil } \\
\text { Mediation Work of the People's Court }\end{array}$ & November 1, 2004 \\
\hline
\end{tabular}




\section{Appendix 2: 2007 Civil Procedure Law of the People's Republic of China}

Chapter 8 Mediation (not amended from 1991)

Article 85 In handling civil cases, the people's court may distinguish between right and wrong and mediate disputes according to the principle of parties' voluntariness and based on clear facts.

Article 86 When a people's court conducts mediation, a single judge or a collegial bench may preside in the mediation. Mediations shall be conducted locally whenever possible.

When a people's court conducts mediation, it may employ simplified methods to notify the parties and witnesses to appear in court.

Article 87 When a people's court conducts mediation, it may request assistance from relevant units or individuals. The invited units or individuals shall assist the people's court in mediation.

Article 88 A mediation agreement must be based on voluntariness of both parties, and shall not be reached through compulsion. The content of the mediation agreement may not contravene the law.

Article 89 When a mediation agreement is reached, the people's court shall draw up a written mediation agreement. A mediation agreement shall clearly set forth the claims of the action, the facts about the case, and the result of the mediation.

The mediation statement shall be signed by the judge and the court clerk, sealed by the people's court, and served on both parties.

Once the mediation agreement is signed and exchanged by both parties, it shall become legally binding.

Article 90 The people's court need not draw up a mediation agreement for the following cases when an agreement is reached through mediation:

(1) Divorce cases in which both parties have become reconciled after mediation;

(2) Adoption cases in which adoptive relationship has been retained through mediation;

(3) Cases in which the claims can be immediately satisfied; and

(4) Other cases that do not require mediation statements.

Any agreement that does not require a mediation agreement shall be entered into the transcript and become legally effective after the transcript is signed or sealed by both parties, the judge, and the court clerk.

Article 91 If no agreement is reached through mediation or if one party retracts his reconciliation before the mediation agreement is served, the people's court shall render a judgment without delay. 
References

ALBERSTEIN, Michal

2002 Pragmatism and Law. Ashgate.

2009 'The Jurisprudence of Mediation: Between Formalism, Feminism and Identity Conversations.' Cardozo Journal of Conflict Resolution 11:1.

CHAN, Kin-man

2009 'Harmonious Society.' Pp. 821-825 in International Encyclopedia of Civil Society. New York: Springer.

CHOW, Debrorah

2002 'Development of China's Legal System will Strengthen its Mediation Programs.' Yeshiva University Cardozo Online Journal of Conflict Resolution 3:4.

COHEN, Jerome

1966 'Chinese Mediation on the Eve of Modernization.' California Law Review 54: 120.

FISHER, Roger and William URY

1983 Getting To Yes: Negotiating Agreement Without Giving In. New York: Penguin Books.

FOLBERG, J. and A. TAYLOR

1984 Mediation - A Comprehensive Guide to Resolving Disputes Without Litigation, San Francisco, Jossey-Bass, 7.

FU, Hualing

1996 'Understanding People's Mediation in Post-Mao China.' Journal of Chinese Law 6: 211.

FU, Hualing and Richard CULLEN,

2011 'From Mediatory to Adjudicatory Justice: The Limits of Civil Justice Reform in China.' Pp.25-57 in Margaret Woo and Mary Gallagher (eds.), Chinese Justice:

Civil Dispute Resolution in Contemporary China. Cambridge University Press.

GILLIGAN, Carol et al.

1988 'Remapping the Moral Domain: New Images of Self in Relationship.' Pp.3-19 in Carol Gilligan et al. (eds.), Mapping The Moral Domain. Harvard University Press.

GLASSMAN, Eric

1992 '"The Function of Mediation in China" Examining the Impact of Regulations Governing the People's Mediation Committees.' UCLA Pacific Basin Law Journal 10: 460-488. 
GORDON, Robert

1994 'Law And Ideology.' Pp.950-959 in Michael Freeman and Dennis Lloyd (eds.), Lloyd's Introduction to Jurisprudence. London: Sweet \& Maxwell. 6th ed.

GUO, Xiang

1986 'Yi Jiu Ba Er Nian Renmin Tiaojie Gongzuo Gaikuang' [A survey of People's Mediation Work in 1982]. Renmin Tiaojie Zai Zhongguo [People's Mediation in China].

HALEGUA, Aaron

2005 'Reforming the People's Mediation System in Urban China.' Hong Kong Law Journal 35: 715.

HART, Henry, Albert SACKS, William ESKRIDGE and Philip FRICKEY

1994 The Legal Process: Basic Problems in the Making and Application of Law. Foundation Press.

HE, Wei and Zeng Ying

2011a 'Extra-judicial Mediation System and Practice (Part I of II)'. Available at: http://www.chinalawinsight.com/2011/10/articles/dispute-resolution/extrajudicialmediation-system-and-practice-ipart-i-of-iii/ (last accessed on 17 March 2013).

2001b 'Extra-judicial Mediation System and Practice (Part II of II)'. Available at: http://www.chinalawinsight.com/2011/11/articles/dispute-resolution/extrajudicialmediation-system-and-practice-ipart-ii-of-iii/ (last accessed on 17 March 2013).

HORWITZ, Morton

1969 The Transformation of American Law 1870-1960: The Crisis of Legal Orthodoxy. Harvard University Press.

HUMPHRIES, Nicolas

1994 'Defending Judicial Heresies: Comparative Law and Value Judgements Regarding Judicial Systems Conformity to the Legalist Model.' Asia Pacific Law Review 3: 1. Special edition.

JI, Weidong

2004 'Current problems with people's mediation agreements and how to solve them' (Dangqian remin tiaojie xieyishu cunzai de wenti yiji jiejiue banfa). People's Mediation (Renmin Tiaojie).

KELMAN, Mark

1987 A Guide To Critical Legal Studies. Harvard University Press.

LI, Xianbo and Wang Huan

2009 'The Application and Development of the Linkage and Interaction System of Three Mediations in Hunan Province.' Asia Pacific Law Review 17: 107-116. 
LOVE, Lela Porter

1997 'Mediation: The Romantic Days Continue.' 38 S. Tex. L. Rev. 735, 741

LUBMAN, Stanley

1967 'Mao and Mediation: Politics and Dispute Resolution in Communist China.' California Law Review 55(5): 1284-1359.

MNOOKIN, Robert and Lewis KOORNHAUSER

1979 'Bargaining in the Shadow of the Law: the Case of Divorce.' Yale Law Journal 88: 950.

NONET, Philippe, Philip SELZNICK and Robert KAGAN

2001 Law and Society in Transition: Toward Responsive Law. Transaction Publishers.

PALMER, Michael

1987 'The Revival of Mediation in the People's Republic of China: (1) Extra-Judicial Mediation.' Pp.219- in William Butler (ed.), Yearbook on Socialist Legal System.

PENG, Bo

2005 'State Control and Governance of Residential Communities (The case to be examined: community mediation in Shanghai).' China perspectives [Online]. Available at http://chinaperspectives.revues.org/1114 (last accessed on 29 July 2012).

SELZNICK, Philip

1992 The Moral Commonwealth. Berkeley: UCLA Press.

SHANGHAI JUSTICE BUREAU

2000 Indispensable Knowledge and Skills for People's Mediation (Renmin tiaojie gongzuo ying zhi ying hui). Shanghai Justice Bureau.

SCHWARCZ, Daniel

2010 'Regulating Consumer Demand in Insurance Markets' 3 Erasmus Law Review 23.

WANG, Liming

2009 'Characteristics of China's Judicial Mediation System.' International Conference on Mediation, City University of Hong Kong. Unpublished manuscript?

WHITE, Edward

1973 'The Evolution of Reasoned Elaboration: Jurisprudential Criticism and Social Change.' Virginia Law Review 59: 279-302.

WANG, Jue

2005 'A Brief Argument on the Foundation for the Enforcement of the Legislations on the People's Mediation' (Jianlun renmin tiaojie lifa de shijian jichu). ZGSF 65: 48-51. 
WANG, Ting

2002 'Extrajudicial Mediation of Civil Disputes in China: The Decline of People's Mediation and Institutional Response.' Department of Government, Harvard College, Unpublished Thesis.

WIBER, Melanie

1995 'Everyday Forms of Violence: Farmer's Experiences of Regulation in the Canadian Dairy Industry.' Journal of Legal Pluralism 35:1-24.

WIBER, Melanie and Maria Recchia

2010 'Legal Pluralism and Integrated Management in Saint John Harbour' Canada.' MAST 9(1):81-101

WU, Xiaohui and Jason QIAN

2010 'Culture of China's Mediation in Regional and International Affairs.' Conflict Resolution Quarterly 28(1): 53-65.

YANG, Na

2000 'Analysis of the People's Mediation System's Current Status' (Renmin Tiaojie Zhidu De Xianzhuang Fenxi). Fazhi Ribao (on 24 September 2000).

ZUMBANSEN, Peer

2008 'Law After the Welfare State: Formalism, Functionalism, and the Ironic Turn of Reflexive Law', 56 Am.J.Comp.L.at 769.

ZHONGGUO FALU NIANJIAN SHE

1986-2001 Law Yearbook of China (Zhongguo Falu Nianjian). Beijing: Zhongguo Falu Nianjian She.

2002 Law Yearbook of China (Zhongguo Falu Nianjian). Beijing: Zhongguo Falu Nianjian She.

2004 Law Yearbook of China (Zhongguo Falu Nianjian). Beijing: Zhongguo Falu Nianjian She.

2006 Law Yearbook of China (Zhongguo Falu Nianjian). Beijing: Zhongguo Falu Nianjian She.

2007 Law Yearbook of China (Zhongguo Falu Nianjian). Beijing: Zhongguo Falu Nianjian She. 